\title{
The Implementation of E-Government in the Context of Good Governance on Judicial Sectors in Indonesia
}

\author{
Jeanny H.V Hutauruk \\ Faculty of Law, Doctoral Program, Universitas Borobudur, Jakarta, Indonesia \\ Email: jeannyhutauruk@yahoo.com
}

\begin{abstract}
At the judiciary, e-Government has started with the initiative launched several years ago. The Implementation of e-govern in the judiciary began running, the prospect was also considered good. This study aims to determine the obstacles and implementation of e-Government to realize good governance in the judiciary in Indonesia. The methodology used in the research is normative which is also often referred to as doctrinal research with object or target of research in the form of regulation, legislation and other legal material. In accordance with the problems encountered in preliminary research, the focus of this analysis and design is on barriers to the judiciary and its implementation. The result is the system that can be developed and utilized by judiciary in Indonesia to achieve a good governance especially in public service.
\end{abstract}

Keywords-e-Government; good governance; the Judiciary

\section{INTRODUCTION}

Indonesia as one of the countries in the world that is struggling and waiting for the reality of expectation on a new shift in the government sector. After a 20-year, through the reform era, Indonesia has been restructuring to Sistem Administrasi Negara Kesatuan Republik Indonesia (SANKRI). Together with the political reforms, that now established as democratic, hence there is also a new development idea of good governance. Restructuring of Sistem Administrasi Negara Kesatuan Republik Indonesia (SANKRI) at the beginning of the reformation era, in fact also had an impact on the judiciary sectors, and that is the integrated unification of 4 judicial sectors in one roof and that is Supreme Court. Before 1998, there was an executive domination in judiciary sectors which made the court not independent and also unprofessional, thus it often led to the practice of corruption, collusion and nepotism. The reformation of Judicial sectors occurred when the Amendment of the 1945 reorganized the constitutional system included the judicial pillars, it triggered the establishment of law enforcement agencies, such as the Judicial Commission, the Constitutional Court and the Corruption Eradication Commission as a step to revamping the mechanism of checks, balances and accountability. Institutional reforms in law enforcement agencies also affect the transfer of administrative authority, judicial finance from the Ministry of Law and Human Right (roofs unification). Another positive impact is that there is no longer a executive monopoly in the management of judges and settlement of cases by the judiciary.

The concept of Good Governance was born in the early reformation era, the people wants to have a high quality government where the corrupt, collusion and nepotism practices are rarely and the certainty of the quality of public services is increasingly better and the government becomes more concerned with their citizens.

The concept of governance simply refers to the process of decision-making and the implementation of governance is applicable and takes place at all levels both nationally and locally (Pierre \& Peters, 2000, p.1). Meanwhile Good governance refers to the existence of accountability, participation, consensus, transparency, efficiency, and effectiveness, responsiveness, equality and inclusiveness and compliance with the rule of law. With these characteristics the realization of Good Governance becomes very important and required.

The concept of Good Governance is the process of carrying out state power in implementing the provision of public goods and services is called governance, while the best practices are called good governance. So that "good governance" can be realized and applicable well, it requires commitment and participation, there are 3 pillars that build Good Governance itself, namely the government, corporations and society. The effective governance is demand good coordination and integrity, professional and work ethic and also high morale. Thus, the application of "good governance" in the state administration is the challenge itself.

In 21 st century, the development of technology and communication science is very rapid. Various information systems applications are used in government agencies known as e-government (Electronic Based Government System). Based on one of the rules in Menteri Pendayagunaan Aparatur Negara dan Reformasi Birokrasi Republik Indonesia Nomor 5 Tahun 2018 sistem pemerintahan berbasis eleketronik (SPBE) or egovernment is a system of governance that utilizes comprehensive information technology and integrated in the implementation of government administration and for 
the provision of public services in government agencies. E-government can be implemented in legislative, judicative, or non-ministerial institutions serving public administration so as to boost an effective, efficient, transparent, accountable and sustainable work processes and to improve the quality of public services as a government effort to increase public confidence by utilizing information and communication technology. The most expected advantage of e-government is the ease of accessibility to the process of governance and administrative services to the public.

From the background above, it is interesting to be researched and appointed as a scientific work with the title "The Implementation of E-Government in the Context of Good Governance on Judicial Sectors in Indonesia”. The problems issued on this paper are concerning to: (1) what are the obstacles in the implementation of e-government to realize good governance in the judicial sectors in Indonesia and how is the solution? and (2) how is the implementation of the Electronic Based Government System (SPBE / E-Government) in realizing good governance in judicial sectors in Indonesia?

\section{RESEARCH METHOD}

This paper includes normative research which is also often referred to as doctrinal research with the object or target of research in the form of regulations, legislation and other legal materials (Mudzakir, p.14). The result of legal research, although not inventing new legal theories, it is at least in the form of new arguments (Marzuki, 2005). This research conducted an normative juridical that is by examining the subject matter as mentioned above. In addition, this research will also complement from other relevant aspects based on the scope and identification of the problem formulated.

\section{RESULT AND DISCUSSION}

\section{A. The Obstacles of the Implementation of E-Government to Achieve Good Governance in the Indonesian Courts}

The obstacles of the implementation of $\mathrm{e}$ government can be seen from the observations made by the Ministry of Communications which concluded that the majority of central government information systems and local governments are still at the level of preparation when viewed from a number of aspects such as:

1. E-leadership : country priorities and initiatives in anticipating and utilizing information technology progress;

2. Information Network Infrastructure: condition of telecommunication infrastructure, quality of infrastructure, and service cost of access to telecommunications services;

3. Information Management: quality and security of information management;

4. Business Environment: market conditions, trading systems and regulations that form the context of the development of information technology businesses;
5. Society and Human Resources: the diffusion of information technology in the community activities both individuals and organizations, and the extent to which information technology is socialized to the community through the education process. There are a number of weaknesses in the formation of egovernment in Indonesia:

6. Services provided by government sites have not been supported by effective management systems and work processes because the readiness of regulations, procedures and limitations of HR greatly limits computerized penetration into the government system;

7. Inadequate strategy and inadequate budget allocated for e-government development;

8. Initiatives are the efforts of individual agencies; thus a number of factors such as standardization, information security, authentication, and basic applications that enable interoperability between systems reliably, safely, and reliably have no policy;

9. The gap in the ability of the community to access the internet network.

By looking at the above conditions, the challenge that arises is how to improve the future implementation of e-government to be more adequate so that no service stages that require face-to-face meetings between communities and public service providers are required. The absence of face-to-face can minimize and eliminate rent seeking activities (profits by using proximity to authorized authorities).

\section{B. Implementation of an Electronic-based Government System (SPBE/E-Government) in Realizing Good Governance in the Indonesian Judiciary}

If you look at the condition of the Indonesian Judiciary in 10 years ago, the access to justice by justice seekers is very difficult. Justice seekers must come directly to the court to find out information about the case, not to mention practices that are less favorable in the case administration process. This certainly makes the image of the judiciary unfavorable in the eyes of justice seekers. However, until now the Supreme Court has done a lot of reform in the judicial sectors (Justice Reform) in order to provide the best service for the community. The update especially started since the 2003-2008 Blue Book Blueprint followed by Blue Book Blueprint 2010-2035. The Blueprint is composed by involving elements of civil society, inviting elements of society, from press to college, so it is not a blueprint solely made unilaterally. Through the blueprint, the Supreme Court has a foothold for reform. Historically disclosure of information to the Supreme Court and its subordinate courts began in 2007 through the application of the Decree of the Chief Justice of the Supreme Court of the Republic of Indonesia No. 144 / KMA / SK / VIII / 2007 concerning Information Disclosure in Court. Then in 2008 through the implementation of Law Number 14 Year 2008 Article 7 states: "Badan Publik wajib menyediakan, memberikan dan/atau menerbitkan Informasi Publik yang berada di bawah kewenangannya kepada Pemohon Informasi 
Publik, selain informasi yang dikecualikan sesuai dengan ketentuan".

Subsequently in 2009, the Supreme Court of the Republic of Indonesia and the judiciary under it adopted Article 52 Paragraph 1 of Act Number 48 of 2009 which states that: "Pengadilan wajib memberikan akses kepada masyarakat untuk memperoleh informasi yang berkaitan dengan putusan dan biaya perkara dalam proses persidangan".

Then in 2011, the Supreme Court issued a Decree of the Chairman of the Supreme Court of the Republic of Indonesia No. 1-144 / KMA / SK / I /2011 on Information Services Guidelines in Courts.

In the period before information technology was applied to the Supreme Court and subordinate courts (before 2007), the publication of decisions was still done conventionally printed on media, such as judicial varia (published every month and containing not more than 3 decisions), jurisprudence books (which are published annually and only contain selected decisions), and several general publications. Thus it can be concluded that at that time access to justice, especially related to the publication of court decisions was still very limited.

Starting in 2011, the Supreme Court of the Republic of Indonesia implemented the publication of decisions centrally through a Directory Application Decision whose management was carried out by the Registrar of the Supreme Court and in its application supported by the Supreme Court Circular Number 14 of 2010 concerning Electronic Documents as Complete Application for Cassation / Reconsideration, Circular Supreme Court Number 1 of 2014 which states that the Directory of Decisions is the only medium for sending electronic documents, and Clerk Circular Number $821 /$ PAN / OT.01.3 / VI / 2014 concerning Guidelines for Managing and Receiving Electronic Documents.

The statistic data in 2016 states that the number of publication of decisions in 2016 was 438,989 (four hundred thirty eight thousand nine hundred eighty nine), if calculated in detail there were 36,582 decisions per month, 1,839 decisions per day, 229 decisions per -hour. Recorded on the Decision Directory Application (https://putusan.mahkamahagung.go.id/), up to August 2017 the number of published decisions amounted to 2,340,877 (two million three hundred forty thousand eight hundred seventy seven) decisions., in August 2017 there were 32,564 (thirty two thousand five hundred sixty four) newly published decisions, and the total of the decisions published in 2017 (August period) were 279,756 (two hundred seventy nine thousand seven hundred five thirtysix) decisions.

The Supreme Court has integrated application of case management information system, namely: Case Information Information System (SIPP). Case Study Information System is an application of recording, tracking and case management based on programming technology. With the application of information technology in the process of acceleration of handling cases, then the register manual cases true can already be abandoned because with the digitalization will change the paradigm of the case becomes paperless.

The existence of management information system applications and case tracking certainly makes it easy for justice seekers to find case information. Aside from being a container in case management, it can also be used as a storage container for digital case files (e-document). When physical case files are lost (with or without accident), you can temporarily use digital files that have been uploaded into the Case Search Information System Application.

The Application of Case Search Information System is one tool that can accelerate the realization of the 2010-2035 Judicial Reform Blueprint. Through the Application of Case Search Information System used by 4 (four) judicial environments this can help accelerate the settlement of cases and realize orderly administration, besides that with the implementation of Case Search Information System in all work units (courts) it will facilitate justice seekers in tracing the process / case files online, so this proves the existence of transparency in the law enforcement process in the court. The Case Search Information System application has the function of control, supervision and evaluation, so that with the existence of this Search Information System Application can encourage work culture towards modern justice based on information technology. Currently, the General Courts of the Supreme Court and other law enforcement agencies, such as: prosecutors, police, and minister of law and human rights (prison) are promoting an integrated crime database (integrated / interoperability) database based on information technology (SPPT TI) Data Application Case Search Information System can communicate, exchange information and share with data from other applications owned by law enforcement agencies. Not only limited to law enforcement agencies, now the Supreme Court also opened up to collaborate with the Ministry of Religious Affairs and DUKCAPIL in build Sistem Informasi Administrasi Kependudukan (SIAK) and Sistem Informasi Manajemen Nikah/Pencatatan Akta Nikah (SIMKAH) implemented for the Religion Courts.

By implementing e-government in the judicial sectors in Indonesia, the utilization of information technology in the judicial sectors can be maximized, so that the number of outstanding cases in the Supreme Court decreases, with a total of approximately 2,357 (two thousand three hundred fifty seven) cases on in 2016. In fact, a few years earlier the amount of arrears in cases could be more than 8,000 (eight thousand). And in 2017 the remaining outstanding cases in the Supreme Court are the lowest in history, namely 1,388 (one thousand three hundred eighty eight) cases, which means smaller than the rest of the previous year. Do not just get there. the use of paper in the work has been reduced by switching using computerized (paperless). And another thing that is not less important is the opportunity for abuse of authority to be reduced. 


\section{CONCLUSION}

Judicial and law enforcement processes have many complex perspectives that often make it difficult to interpret literally. Appropriate understanding can greatly help justice seekers in understanding the process of law enforcement, and in turn will greatly assist the court in carrying out its duties and achieving its vision and mission. The Supreme Court itself has made many efforts to change in the past few years, the purpose of which is to ensure that the performance goes well so that it can break the negative stigma of the Judicial sectors in Indonesia. Thus it can be concluded that the application of EGovernment plays an important role in realizing good governance in the judiciary in Indonesia. But we also cannot turn a blind eye that the application of EGovernment to the Judicial sector in Indonesia still has a number of weaknesses, obstacles and challenges. These obstacles and challenges are still within reasonable limits because the implementation of E-Government in the Judiciary in Indonesia is still relatively new. Because e government in Indonesia's judicial sector plays an important role, it requires policies, rules and regulations that specifically regulate the governance of E-Government in the Indonesian judiciary. Besides that, the availability of budget, and the distribution of human resources in the field of information technology is also still an obstacle that must be reviewed by the Supreme Court and the Judiciary in Indonesia in the application of E-Government to the Judiciary in Indonesia. Another obstacle that is no less important is the geographical factor of the State of Indonesia which has an impact on the uneven distribution of telecommunications infrastructure. The leadership commitment also took part in the successful implementation of E-Government in the Indonesian Judiciary to realize Good Governance in the Judiciary in Indonesia.

\section{REFERENCES}

[1] E. Prasojo dan T. Kurniawan, Hambatan dalam Penerapan E-Government di Indonesia, Laporan Penelitian, DIA FISIP UI, Desember 2004

[2] B. Schwab and D. Kubler, Metropolitan Governance and the "democratic deficit": Theoretical Issues and Empirical Findings, Paper in Conference Area-based initiatives in contemporary urban policy, Copenhagen, May 2001

[3] N. Woods, The Challenge of Good Governance for the IMF and the World Bank Themselves, on World 5 Development, Vol. 28, No. 5, Pergamon, 2000

[4] N. Hague and B. D. Loader, Digital Democracy: Discourse and Decision Making in the Information Age, Routledge, 1999

[5] Holmes, E.gov: E-business Strategies for Government, Nicholas Brealey, 2001

[6] Jon Pierre dan B Guy Peters Governance Politics and the State New York St Martin s Press 2000 hlm 1.

[7] Mudzakir NFN, Metode Penelitian Hukum, Yogyakarta: (Yogyakarta: Program Magister (S2) Ilmu Hukum, Universitas Islam Indonesia,n.d.)

[8] Peter Mahmud Marzuki, Penelitian Hukum (Surabaya: Kencana Prenada Media Group, 2005).

[9] Evaluating e-Government and Good Governance Correlation; Suhardi Suhardi, Alfira Sofia, Agustinus Andriyant, ITB, 2015.

[10] International Journal of Electronic Governance, Prof. Dimitris Gouscos.

[11] Electronic Government (E-Government) and Development, Christian Van Haldenwang, 2016.

[12] Anggono and Dwi I 2015 E-Government Indonesia Update 2015 - 2019 Ministry of communication and information technology the republic of Indonesia

[13] Fang Z 2002 e-Government in Digital Era: Concept, Practice, and Development International Journal of the Computer the Internet and Management 10 1-22

[14] Driss K and Moulin B 2015 E government for good governance in developing countries Empirical evidence from e-Fez project (London New York New Delhi IDRC: Anthem Press)

[15] Alia S, Sabri O and Al-Shargabi B 2012 A Cultural EGovernment Readiness Model Intelligent Information Management

[16] The United Nations E-Government Survey 2016 EGovernment in Support of Sustainable Development. 